\title{
Relative Efficacy of Different Weed Management Practices on Growth, Yield and Weed Dynamics in Sunflower
}

\author{
Prabhuvineeth Inuganti ${ }^{1 *}$, Subhashisa Praharaj ${ }^{1}$, Sagar Lalichetti ${ }^{1}$, Tanmoy Shankar ${ }^{1}$, \\ G.C. Mishra ${ }^{1}$, Sagar Maitra ${ }^{1}$, Rahul Adhikary ${ }^{1}$, Lipsa Patnaik ${ }^{1}$, Sairam Masina ${ }^{1}$ and \\ Sultan Singh ${ }^{2}$
}

${ }^{1}$ Department of Agronomy, M.S. Swaminathan School of Agriculture, Centurion University of Technology and Management, Odisha, India

${ }^{2}$ Division of Agronomy, Sher-e-Kashmir University of Agricultural Sciences and Technology, Jammu, Jammu and Kashmir, India *Corresponding author: prabhuvineeth1997@gmail.com (ORCID ID: 0000-0002-2370-3556)

Paper No. 896

Received: $19-03-2021$

Revised: 25-04-2021

Accepted: 28-05-2021

\begin{abstract}
The experiment was conducted during 2020 to evaluate the relative efficiency of the application of herbicides combined with inter cultivation practices for their influence on the growth and productivity of sunflower. Herbicides like pendimethalin, oxyfluorfen, sodium aciflurfen, clodinafop propargyl with intercultivation at different days after sowing and unweeding as control. Pendimethalin @ $0.75 \mathrm{~kg} / \mathrm{ha}$ at 1 DAS followed by Sodium aciflurofen + Clodinafop propargyl @ $125 \mathrm{~g} / \mathrm{ha}$ at 21 DAS proved to be better in terms of effective weed control, improved crop growth characters, and productivity of sunflower. The performance of Oxyfluorfen @100 g/ha at 1 DAS fb Sodium aciflurofen + Clodinafop propargyl @150 g/ha at 21 DAS was on par with Pendimethalin @ $0.75 \mathrm{~kg} /$ ha at 1 DAS followed by Sodium aciflurofen + Clodinafop propargyl @ $125 \mathrm{~g} /$ ha at 21 DAS with regard to growth, yield attributes and seed yield.

\section{HIGHLIGHTS}

( Sodium aciflurofen + Clodinafop propargyl herbicide is tested in this experiment which was recommended in soybean.

( Pre-emergence application of pendimethalin @ $0.75 \mathrm{~kg} /$ ha at 1 DAS followed by sodium aciflurofen + clodinafop propargyl @ $125 \mathrm{~g} / \mathrm{ha}$ at 21 DAS emerged as the most efficient method.
\end{abstract}

Keywords: Sunflower, herbicides, weed density, dry weight, growth and yield

Sunflower (Helianthus annuus L.), also known as "Surajmukhi," is one of the most important oilseed crops having global recognization. In India, sunflower is cultivated in an area of 2.80 lakh hectares with a production of 2 lakh tonnes and productivity of $527.5 \mathrm{~kg} \mathrm{ha}^{-1}$ (Anonymous 2018). It is known for its hardiness attributed due to photo-insensitivity and low water requirement. The sunflower oil was nutritionally rich and known for high linoleic acid content and good taste. Weed problem poses a serious threat to sunflower competing for nutrients, light, space, and water. On the other hand, weeds may also serve as an alternate host to various pests and diseases, resulting in a reduction in yield drastically. A study
(Daugovish et al. 2003) showed that a massive weed competition decreases the sunflower's ability to function by around 58 percent. However, the adoption of conventional methods of weed control was found to be inefficient in controlling the weeds. A study indicated, pre-emergence application of pendimethalin@1.0 kg/ha followed by one hand weeding at 30 DAS is the best practice for getting effective weed control in irrigated sunflower (Selvakumar et al. 2018). Hence, there is an urgent

\footnotetext{
How to cite this article: Inuganti, P., Praharaj, S., Lalichetti, S., Shankar, T., Mishra, G.C., Maitra, S., Patnaik, L., Masina, S. and Singh, S. 2021. Relative Efficacy of Different Weed Management Practices on Growth Yield and Weed Dynamics in Sunflower. IJAEB, 14(2): 181-184.

Source of Support: None; Conflict of Interest: None $\infty$
} 
need to compare the relative efficacy of different herbicides solely and in combination with different cultural methods to find out the most efficient technology discouraging the weed establishment in the sunflower field, especially during a critical period. Since information available on efficient herbicide-based weed management practice is meager. Keeping this in view, the present study was designed to study the relative efficacy of different weed management practices on growth, yield and weed dynamics in sunflower.

\section{MATERIALS AND METHODS}

The field experiment was conducted during Rabi-2020 at Research Farm, Bagusala, Centurion University of Technology and Management, Parlakhemundi, Odisha. The experimental site was located at $18.80^{\circ} \mathrm{N}$ latitude and $84.20^{\circ} \mathrm{E}$ longitude, at an elevation of $145 \mathrm{~m}$ above mean sea level. It is located in North-Eastern Ghat Zone of Odisha. The soil of the experimental site was sandy loamy... in texture, slightly acidic in reaction (.PH 6.9), low in organic carbon $(0.59 \%)$, available nitrogen (160 $\mathrm{Kg} / \mathrm{ha}$.) and medium in phosphorus (12kg/ha) and potassium $(150 \mathrm{~kg} / \mathrm{ha})$. The experiment was laid out in a Randomized block design with three replications. Seeds of "Surya" variety were sown at $60 \times 30 \mathrm{~cm}$ spacing during the period of investigation. The experiment consisted of nine treatments viz. T1 (Pendimethalin@ $0.75 \mathrm{~kg} / \mathrm{ha}$ at 1 DAS + Inter cultivation at 15 and 30 DAS); T2 (Oxyfluorfen @ 100 $\mathrm{g} /$ ha at $1 \mathrm{DAS}+$ Inter cultivation at 15 and $30 \mathrm{DAS}$ ); T3 (Sodium aciflurofen + Clodinafop propargyl @ $125 \mathrm{~g} / \mathrm{ha}$ at $21 \mathrm{DAS}$ ); T4 (Pendimethalin @ 0.75 $\mathrm{kg} / \mathrm{ha}$ at 1 DAS followed by Sodium aciflurofen + Clodinafop propargyl @125 g/ha at 21 DAS); T5 (Oxyfluorfen @100 g/ha at 1 DAS fb Sodium aciflurofen + Clodinafop propargyl @150 g/ha at 21 DAS); T6 (Inter cultivation at 15 and 30 DAS); T7 (Straw mulching @ 5.0 t/ha at 30 DAS); T8 (Weed free); T9 (Un weeded control). Weed samples were collected with the help of a quadrate of $0.25 \mathrm{~m}^{2}$ from four places in each plot to determine total weed density, as well as the dry weight of the weed Weed dry weight, was recorded after drying the weed samples at $72^{\circ} \mathrm{C}$ till constant weight was recorded. Weed density and dry weight were square roots transformed before analysis. The growth, yield, and yield attributes were recorded viz plant height, the number of leaves per plant, stem girth, head diameter, no. of seeds per head, 100 seed weight, and grain yield. Further, all the data were statistically analyzed for randomized block design at $5 \%$ level of significance

\section{RESULTS AND DISCUSSION}

Weed density significantly effects on weed dry weight if the weed density is less similarly the weed dry weight is less and there is lesser weed density the competition between the crop and weed for moisture, nutrients, space is less growth parameters like plant height, stem grith, head diameter is more growth parameters is higher yield of the crop brief details about the experimental details about the weed density and weed dry weight and their impact on growth parameters like plant height, stem grith. Number of leaves/plant number of seed/head, head diameter, yield are discussed below

\section{Weed density and dry weed weight}

Among the weed control treatments, pendimethalin $@ 0.75 \mathrm{~kg} / \mathrm{ha}$ at $1 \mathrm{DAS}$ followed by Sodium aciflurofen + Clodinafop propargyl @ $125 \mathrm{~g} /$ ha at 21 DAS (T4) was effectively controlling the weed density and total weed dry weight of the weed species present in the experimental field. This might be due to the prevention of germination of weed seeds which also controlled the growth of germinated weed seeds. The similar favourable effect of -pre-emergence application of pendimethalin (Rao et al. 2009; Arvadiya et al. 2012), on lowering the weed density. Dobariya et al. (2015) that pendimethalin at $1.0 \mathrm{~kg}$ $\mathrm{ha}^{-1}$ as the pre-emergence application with one inter culturing at 25 DAS recorded lower weed dry weight and higher weed control efficiency (Verma et al. 2015, Table 1).

\section{Growth parameters}

Data recorded on plant height, number of leaves per plant, stem girth at 90 DAS (Table 2) was significantly higher in the Pendimethalin @ 0.75 $\mathrm{kg} / \mathrm{ha}$ at 1 DAS followed by Sodium aciflurofen+ Clodinafop propargyl @125 g/ha at 21 DAS. Higher plant height might be due to better weed control in the above treatments which resulted in utilization of light, water and nutrients by the crop effectively than other treatments. Weed-free environment increased the plant height and dry 
Table 1: Effect of treatments on total weed density and weed dry weight at different crop growth stages

\begin{tabular}{|c|c|c|c|c|c|c|}
\hline \multirow{2}{*}{ Treatments } & \multicolumn{3}{|c|}{ Total weed density $\left(\mathrm{g} / \mathrm{m}^{2}\right)$} & \multicolumn{3}{|c|}{ Weed dry weight $\left(\mathrm{g} / \mathrm{m}^{2}\right)$} \\
\hline & 30 DAS & 45 DAS & 60 DAS & 30 DAS & 45 DAS & 60 DAS \\
\hline $\begin{array}{l}\text { Pendimethalin @ } 0.75 \mathrm{~kg} / \mathrm{ha} \text { at } 1 \text { DAS } \\
\text { + Inter cultivation at } 15 \text { and } 30 \text { DAS }\end{array}$ & $* * 7.55 *(56.50)$ & 7.95 (62.81) & 8.08 (64.75) & $* * 5.43 *(28.96)$ & $5.56(30.47)$ & $5.74(32.43)$ \\
\hline $\begin{array}{l}\text { Oxyfluorfen @ } 100 \mathrm{~g} / \text { ha at } 1 \text { DAS + } \\
\text { Inter cultivation at } 15 \text { and } 30 \text { DAS }\end{array}$ & $7.86(61.26)$ & $8.52(72.06)$ & $8.62(73.79)$ & $5.84(33.65)$ & $5.96(35.07)$ & $6.20(37.98)$ \\
\hline $\begin{array}{l}\text { Sodium aciflurofen + Clodinafop } \\
\text { propargyl @ } 125 \mathrm{~g} / \mathrm{ha} \text { at } 21 \text { DAS }\end{array}$ & $9.03(81.11)$ & 9.57 (91.01) & $9.41(88.06)$ & $6.82(45.95)$ & $7.03(48.94)$ & 7.07 (49.47) \\
\hline $\begin{array}{l}\text { Oxyfluorfen @ } 100 \mathrm{~g} / \mathrm{ha} \text { at } 1 \text { DAS fb } \\
\text { Sodium aciflurofen + Clodinafop } \\
\text { propargyl @ } 150 \mathrm{~g} / \mathrm{ha} \text { at } 21 \text { DAS }\end{array}$ & $6.16(37.49)$ & $6.61(43.18)$ & $6.49(41.66)$ & $4.56(20.34)$ & $4.81(22.64)$ & $4.98(24.31)$ \\
\hline Farmers practice & $6.98(48.29)$ & $7.57(56.84)$ & $7.85(61.11)$ & $4.98(24.35)$ & $5.22(26.73)$ & $5.33(27.86)$ \\
\hline Unweeded (control) & $11.84(139.67)$ & $11.89(141.01)$ & $12.03(144.21)$ & $9.21(84.34)$ & $9.28(85.62)$ & $9.39(87.66)$ \\
\hline SEM $( \pm)$ & 0.07 & 0.09 & 0.15 & 0.07 & 0.06 & 0.07 \\
\hline $\mathrm{CD}(5 \%)$ & 0.16 & 0.20 & 0.31 & 0.15 & 0.14 & 0.15 \\
\hline
\end{tabular}

*Figures in parentheses are original values; ${ }^{* *}(\sqrt{ } X+0.5)$ transformed value.

Table 2: Effect of treatments on crop growth and yield attributes of Sunflower

\begin{tabular}{|c|c|c|c|c|c|c|c|}
\hline Treatments & $\begin{array}{l}\text { Plant } \\
\text { height } \\
(\mathrm{cm})\end{array}$ & $\begin{array}{l}\text { Number of } \\
\text { leaves/plant }\end{array}$ & $\begin{array}{l}\text { Stem } \\
\text { girth }(\mathrm{cm})\end{array}$ & $\begin{array}{l}\text { Head } \\
\text { diameter } \\
(\mathrm{cm})\end{array}$ & $\begin{array}{l}\text { Seeds/ } \\
\text { head }\end{array}$ & $\begin{array}{l}100 \text { seed } \\
\text { weight } \\
\text { (g) }\end{array}$ & $\begin{array}{l}\text { Grain } \\
\text { Yield } \\
\text { (Kg/ha) }\end{array}$ \\
\hline $\begin{array}{l}\text { Pendimethalin @ } 0.75 \mathrm{~kg} / \mathrm{ha} \text { at } 1 \mathrm{DAS}+\text { Inter } \\
\text { cultivation at } 15 \text { and } 30 \text { DAS }\end{array}$ & 164.66 & 10.00 & 8.65 & 15.20 & 985.00 & 1.54 & 845.00 \\
\hline $\begin{array}{l}\text { Oxyfluorfen @ } 100 \mathrm{~g} / \mathrm{ha} \text { at } 1 \text { DAS + Inter } \\
\text { cultivation at } 15 \text { and } 30 \text { DAS }\end{array}$ & 160.32 & 10.00 & 8.59 & 15.10 & 954.00 & 1.50 & 795.00 \\
\hline $\begin{array}{l}\text { Pendimethalin @ } 0.75 \mathrm{~kg} / \mathrm{ha} \text { at } 1 \text { DAS } \\
\text { followed by Sodium aciflurofen + } \\
\text { Clodinafop propargyl @ } 125 \mathrm{~g} / \mathrm{ha} \text { at } 21 \text { DAS }\end{array}$ & 180.32 & 13.00 & 10.20 & 16.90 & 1105.00 & 1.61 & 986.00 \\
\hline $\begin{array}{l}\text { Oxyfluorfen @ } 100 \mathrm{~g} / \mathrm{ha} \text { at } 1 \text { DAS fb Sodium } \\
\text { aciflurofen + Clodinafop propargyl @150 g/ } \\
\text { ha at } 21 \text { DAS }\end{array}$ & 179.55 & 12.00 & 9.86 & 16.30 & 1095.00 & 1.60 & 975.00 \\
\hline Farmers practice & 177.88 & 11.00 & 8.74 & 15.50 & 1080.00 & 1.61 & 964.00 \\
\hline Unweeded (control) & 125.33 & 6.00 & 8.09 & 11.24 & 686.00 & 1.37 & 523.00 \\
\hline $\operatorname{SEM}( \pm)$ & 3.62 & 0.16 & 0.21 & 0.33 & 22.74 & 0.03 & 12.84 \\
\hline $\mathrm{CD}(5 \%)$ & 7.67 & 0.34 & 0.45 & 0.69 & 48.22 & 0.06 & 27.21 \\
\hline
\end{tabular}

matter production in groundnut (Singh and Giri 2001; Pandian and Nambi 2002). A higher number of leaves was due to the integration of preemergence herbicides provided better weed control by decreasing the weed density and dry matter thus reduced weed competition thereby facilitated the better utilization of crop growth resources. It is reflected in increasing the number of functional leaves. A similar favorable effect on crop growth was earlier viewed by Changsaluk et al. (2005), Tahir et al. (2009) with Pendimethalin. 


\section{Yield and Yield attributes}

Yield attributes such as head diameter, 100-seed weight, and seed yield were favorably influenced by weed control treatments (Table 2). Lesser weed competition during a critical period of crop growth resulted in enhanced yield attributing characters. Pendimethalin @ $0.75 \mathrm{~kg} / \mathrm{ha}$ at 1 DAS followed by Sodium aciflurofen + Clodinafop propargyl @125 g/ ha at 21 DAS (T4) recorded higher head diameter, 100 seed weight, and seed yield. Muro et al. (2001), Barros et al. (2004) reported that the number of seeds head-1 is typically the most affected yield components by various biotic and abiotic stresses, which ultimately reflects in lower sunflower yield. Superior yield attributes might be due to better growing environment throughout the crop growth by proper weed check and lowering down the competition due to weeds which favored the sunflower crop to utilize the available resources to the maximum extent, which reflected on higher growth and yield attributing characters.

\section{CONCLUSION}

In the light of the above observations recorded, it can be concluded that pre-emergence application of Pendimethalin @ $0.75 \mathrm{~kg} / \mathrm{ha}$ at 1 DAS followed by Sodium aciflurofen + Clodinafop propargyl @ $125 \mathrm{~g} /$ ha at 21 DAS is the efficient method of weed control for irrigated sunflower over all other methods under comparison

\section{REFERENCES}

Anonymous, 2018. Directorate of Oilseeds Development, Government of India, Ministry of Agriculture \& Farmers Welfare. Department of Agriculture, Cooperation \& Farmers Welfar, Hyderabad.

https://oilseeds.dac.gov.in (23-04-2021 4:57 PM)

Arvadiya, L.K., Raj, V.C., Patel, T.U. and Arvadiya, M.K. 2012. Influence of plant population and weed management on weed flora and productivity of sweet corn (Zea mays). Indian J. Agron., 57: 162-167.
Barros, J.F., de Carvalho, M. and Basch, G. 2004. Response of sunflower (Helianthus annuus L.) to sowing date and plant density under Mediterranean conditions. Eur. J. Agron., 21: 347-356.

Changsaluk, S., Suwanketnikom, R. and Lim-Aroon, S. 2005. Efficacy of isoxaflutole for weed control in sweet corn. In proceedings of $43^{\text {rd }}$ Kasetsart University Annual Conference, Thailand, 1-4 February, Plants and Agricultural Extension and Communication. Pages 721-727. https://www.cabdirect.org/cabdirect/ abstract/20163376016(23-05-2021,02:30 pm)

Daugovish, O., Thill, D.C. and Shaft, B. 2003. Modeling competition between wild oat (Avena fatua L.) and yellow mustard or canola. Weed Sci., 51: 102-109.

Dobariya, V.K., Mathukia, R.K., Gohil, B.S. and Chhodavadia, S.K. 2015. Integrated weed management in rabi sweet corn (Zea mays var. saccharata). J. Eco- Frie. Agri., 10: 70-83.

Muro, J., Irigoyen, I., Militino, A.F. and Lamsfus, C. 2001. Defoliation effects on sunflower yield reduction. Agron. J., 93: 634-637.

Singh, V.B. and Giri, G. 2001. Influence of intercropping and weed control measures on dry matter accumulation and nutrient uptake by sunflower and groundnut and their effect on succeeding maize. Indian J. Agron., 46: 50-55.

Selvakumar, T., Srinivasan, K. and Rajendran, L. 2018. Performance of chemical weed management in irrigated sunflower. Int. J. Agric. Sci., ISSN, 0975-3710. https://www. researchgate.net/publication/328601662 (18-05-2021,02:00 pm)

Pandian, B.J. and Nambi, J. 2002. Use of herbicide in groundnut based intercropping system. Pestol., 14: 21-25.

Rao, A.S., Ratnam, M. and Reddy, T.Y. 2009. Weed management in zero-till sown maize. Indian J. Weed Sci., 41: 46-49.

Verma, S., Verma, D.K., Verma, S.P., Giri Singh, K., Singh, R.B. and Pandey, A. 2015. Response of chemical weed management in maize and cowpea intercropping system grown for quality fodder in Eastern Uttar Pradesh. Int. J. Fore. Crop Imp., 6: 105-109.

Tahir, M., Javed, M.R., Tanveer, A., Nadeem, M.A., Wasaya, A., Bukhari, S.A.H. and Rehman, J.U. 2009. Effect of different herbicides on weeds, growth and yield of spring planted maize (Zea mays L.). Pak. J. Life Soc. Sci., 71: 168-174. 